\title{
Audiences and interpretations ${ }^{1}$
}

\author{
Sonia Livingstone ${ }^{2}$
}

\begin{abstract}
This article draws on recent developments on communication research to explore the concept of the active audience and the processes of interpreting media texts. Using the important contribution of Stuart Hall's encoding/ decoding model as a starting point, I advocate a perspective in which audience reception is seen as structured by textual as well as by (psycho)social factors. However, the processes of comprehension and interpretation should not be seen as deterministically bounded by these factors. Instead, they must first be distinguished from each other and, second, both must be understood in relation to textual and social opportunities for openness, contradiction, agency, polysemy, ambiguity, etc. I argue that new empirical research needs to be conducted if further steps are to be taken to better understand when, where and under what circumstances different kinds of sense-making occur during these processes.
\end{abstract}

Key words: Audience; moment of reception; comprehension; interpretation

Resumo: Este artigo se apóia nos desenvolvimentos recentes em pesquisas de comunicação para explorar o conceito de audiência ativa, assim como os processos de interpretação dos textos midiáticos. Usando a importante contribuição do modelo de codificação/ decodificação de Stuart Hall como ponto de partida, defendo uma perspectiva na qual a recepção da audiência é vista como estruturada tanto por fatores textuais quanto (psico)sociais. Entretanto, os processos de compreensão $e$ interpretação não devem ser entendidos como restritos por estes fatores. Ao contrário, eles devem ser distinguidos entre si, para depois serem entendidos em relação às oportunidades textuais e sociais de abertura, contradição, agenciamento, polissemia, ambigüidade etc. Argumento que novas pesquisas empíricas devem ser conduzidas, se quisermos dar novos passos para entender melhor quando, onde, $e$ sob quais circunstâncias, diferentes tipos de entendimento ocorrem durante estes processos.

Palavras-chave: Audiência; momento da recepção; compreensão; interpretação

\footnotetext{
${ }^{1}$ Este artigo é uma versão modificada e atualisada do capítulo 8 do livro Making sense of television: The psychology of audience interpretation (London: Routledge, 1998).

${ }^{2}$ Professora do departamento de comunicação e mídia da London School of Economics. Ela também é presidente da International Communication Association (http://www.icahdq.org) e diretora do projeto EUKidsOnline (www.eukidsonline.net). Autora de inúmeros livros, entre eles, Making Sense of Television (2nd edition, Routledge, 1998); Mass Consumption and Personal Identity (with Peter Lunt; Open University Press, 1992); Talk on Television (with Peter Lunt; Routledge, 1994); Young People and New Media (Sage, 2002); Audiences and Publics (edited; Intellect, 2005); Harm and Offence in Media Content (with Andrea Millwood Hargrave; Intellect, 2006); Media Consumption and Public Engagement (with Nick Couldry; Palgrave, 2007).
} 


\section{The Active Audience}

The notion of the active audience remains controversial. Is an active audience alert, attentive and original? Is he or she politically active or subversive? Does the active audience represent anything other than a challenge to the straw person of the 'passive audience'? To reject the extreme do-what-you-will-with-the-text model of the active audience is not necessarily to reject a vigilant, attentive and creative audience, and nor is it necessarily to accept a habitual, unimaginative one. Audiences must inevitably 'do' something with the text and they draw upon their formidable resources of knowledge and experience to do so. However, an approach which proposes an active audience also requires a complex conception of the text in order to adopt an interpretive approach to text and reader simultaneously.

Media texts, like other texts, are multilayered, subject to conventional and generic constraints, open and incomplete in their meanings, providing multiple yet bounded paths for the reader. As a result textual complexity, which is inevitably encountered as soon as empirical research begins, need not be regarded as noise or nuisance, nor presumed by implicit appeals to the commonsense of the academic reader. If one does not expect single, given meanings, then one need not be disturbed by the difficulties of finding them. Rather one will be prepared for the structural complexity and indeterminacy of actual media texts - television programmes, magazines, websites, etc - as of course the audiences have to be.

Recent theoretical developments in audience research, by rightly providing further layers of contextualisation around the process of audience engagement, are tending to ignore the actual moment of interpretation which is crucial to the construction and reproduction of cultural meanings (Livingstone, 2007). In this article, I focus on that moment of interpretation by audiences and offer a rethinking of the interpretative process, informed by research in both audience reception/interpretation and audience ethnography/contextualisation.

The concept of 'the person as reader' assumes that the reader is skilled, knowledgeable, motivated, receptive. A reader cannot be completely passive, for the words will remain a blur of black and white marks, and so to the audience cannot be completely passive, for the media text will remain meaningless. Hence theories of powerful effects, with their hypodermic imagery, or notions of inevitable and 
unavoidable social representations, require thinking. But neither can readers be wilful, turning Alice through the looking glass into a statistics text book or social realist novel (though they may see it as a funny children's book, a philosophical exercise, or even advise on playing chess). The 'tool-kit' model cannot be applied to the reader, for readers are constrained by the structure of the text. So too are audiences constrained in their interpretations of media texts, so that certain readings are aberrant; one cannot create any meanings at will.

It becomes important, then, to examine the social knowledge of the reader, to conceive of readers in relation to texts and texts in relation to readers and to study the activities of actual readers, with all the methodological problems that this brings with it. One can then ask how people relate their knowledge of the world to the world of the media, how the interpretations they make of media texts fit or challenge their prior experiences and the role of their knowledge in directing divergence in interpretations.

\section{Comprehension and Interpretation}

What is involved in making sense of media? In the following discussion I will retain the terms understanding, decoding and sense making as the general terms, and use other terms where appropriate to describe more specific ways in which understanding or making sense of a media text is achieved. The term 'reader' is also useful, for it foregrounds the reader-response approach which sees texts as multiple rather than as singular in meaning, and which conceives of texts and readers as related rather than independent. The term 'audience reception' is a more general one, focusing on interpretative processes, and locating these within the context of the domestic, cultural, discursive and motivational processes which both precede and follow viewing.

I will start by considering two classic attempts to account for the process of audience understanding (Corner 1995; Lewis, 1991), each of which elaborates the process involved in making sense of television. Each is grounded in Hall's (1994) encoding/decoding model and attempts to hold onto its strengths, particularly its emphasis on the text as a crucial moment in the circulation of meanings, while acknowledging the ways in which the field has moved on. Each also seeks to ask, in relation to making sense of the news, for example, both how well people remember 
the news, what they gain from a public information campaign, or whether they are informed by election broadcasts during an election campaign, as well as asking what meanings actually result from these and other media experiences and what contextual resources frame these meanings; that this may direct our attention towards different aspects of the television programme as text is not inherently problematic.

In discussing Condit's (1989) analysis of audience responses to an abortion decision in Cagney and Lacey, Lewis agrees with Condit that the openness of television programmes and the activity of viewers have been overstated. Lewis's (1991) account of making sense of television proposes two component processes. He suggests that in most cases viewers agree on the comprehension of the episode, i.e. on what has happened, and so make similar plot summaries, but disagree on their interpretation, where this is largely theorised as an evaluative judgement. In the case of Condit's study, viewers disagree because some are pro- and others are antiabortion, and this is obviously a characteristic of viewers which precedes their response to a particular narrative. Corner's (1995) approach probably reflects more commonly held assumptions, albeit often not made explicit, about the decoding process. He proposes a three step approach, thereby allowing for a more complex theory of the text and a more active model of the reader/viewer. First, comprehension refers to the process of decoding the denotative level of textual meaning. Second, the connotative level of textual meaning is decoded through processes of implication and association. Lastly, the viewer's response to these decoded meanings depends on his or her own contextual and personal circumstances.

Comprehension focuses on the extent to which texts, however complex, may be said to convey information, or the extent to which certain readings may be fairly judged correct or incorrect. Interpretation focuses on the ways in which texts involve narrative or conventional frames, create cultural connections and resonances and implicate mythic or ideological meanings. Insofar as interpretations depend on the contingent contribution of the reader, they cannot be judged as either correct or mistaken but rather must be seen as a product of the reader's experience which generated them, or as more or less plausible given prevailing normative assumptions, or as more or less creative, critical or interesting. 
Traditionally, audience researchers who take a cognitive psychology or administrative approach have found comprehension more interesting, for it depends on people's basic knowledge structures, while critical audience researchers have found interpretation more interesting for it reveals the cultural and contextual factors which differentiate among viewers. While each approach has addressed itself to a different aspect of the text, clearly both comprehension and interpretation occur when making sense of television. If research on comprehending and remembering television programmes is to be productively integrated with, rather than somehow oppositional to, research on ideological interpretation and framing, how should this be advanced?

The case for integrating comprehension and interpretation depends in part on one's starting point. To put it simply, it seems that the critical media scholar traditionally neglects comprehension processes, while the cognitive psychologist has traditionally incorporated the sociocognitive account of comprehension but has been less sensitive to more interpretative processes. Particularly, the focus among audience reception theorists on relatively open, interpretative or associational/evaluative processes has been intended to stress that audience reception is a variable process rather than an automatic function of the nature of the 'information' postulated by information-processing theories of sociocognitive psychology. The notion of 'information' usually implies unitary and given meaning while 'processing' suggests a single, linear set of automatic transformations carried out on that information, thereby making researchers blind to the possibility of interpretative divergence. Thus, interpretation is fundamentally socially located so that the experience and knowledge of the reader plays a central role in decoding the text.

While emphasising the dangers of the information-processing approach, I would also caution against taking these arguments to exclude any consideration of textual constraints on audience reception. For surely one would not wish to say that texts do not contain information, nor that questions of accuracy or miscommunication are irrelevant; the viewers who hear forty people instead of fourteen were killed in a plane crash, or the child who thinks the detective committed the crime, because she or he sees the detective re-enact the crime to establish the means, are clearly wrong or have missed the point - hence Eco’s (1979) distinction between divergent readings and aberrant readings. It must be legitimate and sometimes important to ask whether 
viewers receive specific programme information or whether specific textual biases are mirrored by the viewers. Thus, cognitive psychologists ask whether children can decode a narrative to discover 'who done it' or whether they can tell the baddies from the goodies (Collins, 1983; Messenger Davies, 1989). Using similar assumptions, researchers may check the psychological reality of content analyses by asking whether particular contents are received by viewers, provided it is acknowledged that such questions depend on information-processing assumptions, conceiving of meaning as unitary and as given by the text and only giving viewers the power to agree or disagree with this meaning. However, advances in both semiotic and audience theories require that this match/mismatch conception of the role of the viewer be integrated with a view of the text as polysemic and open and with a view of audiences as actively constructive in their interpretations.

The importance of distinguishing comprehension from interpretation (or inference and association) may be grounded theoretically, as well as justified through empirical observation of the kinds of interpretative divergence which actually occur. Starting from the text, Hall (1980) defined denotation and connotation by distinguishing 'those aspects of a sign which appear to be taken, in any language community at any point in time, as its "literal" meaning (denotation) from the more associative meanings for the sign which it is possible to generate (connotation)' (p.133, my italics). By stressing that both denotation and connotation are contingently defined and socially negotiated, Hall shifts the usage of these terms from referring to levels of meaning inherent in the text (to do with surface and deep meanings) towards meanings which depend on the shared, fragmented or conflictual nature of the social circumstances of both encoding and decoding. On this definition, denotation is primarily defined in terms of consensual and taken-for-granted meanings, and so would be expected to result in consensual readings among viewers. On the other hand, connotation depends on the particular and various conditions which make particular meanings more or less possible (or implausible), for it is here that 'situational ideologies alter and transform signification' (Hall, 1980, p.133), and so here one would expect more interpretative divergence. Even though most work following the encoding/decoding model investigates audience decoding of connotative meanings, and regards studying the decoding of denotation as a reversion to the much criticised 
transmission model of communication (Carey, 1989), nonetheless Hall would seem to be inviting work on audience decoding at both levels, for both represent 'the different levels at which ideologies and discourses intersect' (p.133).

For Lewis to reduce interpretation to a kind of attitudinal judgement (e.g. whether the viewer is pro- or anti-abortion) is to oversimplify, but his aim is to suggest that during the practice of viewing, such cultural complexities may become translated into a series of evaluative responses which colour, but do not alter the substance of, viewers' decodings of television. The problem is that, as Osgood et al. (1957) argued some time ago, evaluation is an inherent part of meaning and exerts a strong 'top-down' influence on the inferences and associations which are made. Further, Corner's term 'response', being somewhat ill-defined, is probably best kept as a highly general term, encompassing both comprehension and interpretation, cognitions and emotions, actions during and following viewing (otherwise, it is potentially confusing as part of both stimulus-response and reader-response terminology). I suggest instead that what Lewis and Corner propose as a separate process rather refers to the set of discursive resources on which making sense of television, both comprehension and interpretation, depends. These in turn depend on the viewers' social and cultural positioning. In other words, viewers' response, or evaluative interpretation, is not so much a distinct interpretative process but a shorthand to remind us of the many extra-textual resources on which viewers may draw when making sense of television (their beliefs, understandings, emotional concerns, social knowledge, etc.; a reference to the rest of their lives, in short).

The distinction between textual and extra-textual codes or knowledge is largely a pragmatic one, allowing differentiation among research questions which take as their starting point the television programme or the viewers' everyday lives. One can thereby distinguish audience research questions in terms of whether they are concerned with viewers' social knowledge resources in recognising and understanding the specific textual codes and invitations of a television programme, or whether they are concerned with the meanings and practices of people's everyday life which they bring to understanding television (and to understanding everything else). To ask about the relation between encoding and decoding, or between the model and actual reader, is to ask both kinds of questions simultaneously: what do programmes 
'expect' of their viewers (“the implied reader”), and what do audiences 'bring' to making sense of television ("the actual reader")? In other words, we may ask whether viewers possess, and use, the kinds of knowledge invited from them by the programme, and we may also ask the separate but overlapping question of what kinds of knowledge viewers actually possess and use when understanding a television programme. Thus I want to retain a focus on the specifics of interpreting texts, which otherwise tend to get lost in the current broad interest in the consumption and appropriation of media in everyday life, without necessarily prioritising either the specific question of local textual interpretation or the general question of the circulation of meanings in everyday life.

Importantly, Corner sees 'viewer response' as more concerned with the viewer's side of things, which seems to imply that other processes are not. While the nuts and bolts of recognising words, making use of story grammars or other generic schemas, and all the other processes of actually comprehending television programmes, has not particularly interested more critical or hermeneutically-oriented researchers to date, that does not imply that little 'viewers' work' (Katz, 1996) goes on here also. As discussed above, such a neglect may be understandable, for it may also be that this level of viewers' work results in less divergence in decoding, is less engaged with the openness of texts, or is less likely to result in politically interesting (i.e. resistant) readings. But even this conclusion would be premature, given the relatively small body of work conducted on the comprehension of real-life (i.e. not experimentally manipulated) television programmes.

There are at least two sizeable bodies of research literature which are concerned with comprehension rather than more open or complex forms of interpretation. I would single out that concerned with news, especially with why ordinary viewers appear to so frequently misunderstand or forget the television news (Graber, 1988; Gunter, 1987), and that concerned with child viewers, especially with why children of different ages make sense of, or misunderstand, even simple television narratives in different ways (Dorr, 1986; Hodge \& Tripp, 1986). Both literatures indicate ample opportunity for viewers' work, including active or divergent readings - in relation to both comprehension and interpretation. 
While each of these processes involves considerable work on the part of the viewer, Corner's process of response is less directly cued by, or tied to, the structures of the text than are comprehension and interpretation. Corner is clearly right to stress the point that crucial interpretative processes are importantly text-led. For, using his terms for a moment, comprehension is getting the message from the text, putting the words together correctly, etc, and implication/association refers, presumably, to the ways in which viewers respond to the implications offered by the text (interestingly, he does not label this 'inference' - a more viewer-led process).

It must be admitted that the business of identifying component processes or phases in the production of meanings from media texts is a hazardous one; the only point in trying is if the analytic gain exceeds the confusion which each scheme seems to generate. Nonetheless, I propose that, instead of identifying three processes (comprehension, interpretation, response) involved in making sense of television which move from those which demand rather little of the viewer to those which demand much, we can identify two processes (comprehension and interpretation), both of which place considerable, although different, demands on the viewer, and both of which make more or less use of textual and extra-textual knowledge. However, the process of interpretation is far richer than that proposed by Lewis, and nor does it necessarily come after comprehension in a sequence of sense-making.

The concept of extra-textual knowledge, encompassing as it does, many aspects of viewers' lives, represents something of a bottomless pit in audience reception analysis (as too, of course, does the concept of contextualised response). However, rather than including everything which might relate to viewers' response as a component part of the process of making sense of television, I would rather emphasise that while many aspects of viewers' lives might relate to any aspect of sense-making, it is preferable to retain the distinction between these potential resources and the process of making sense of television (just as Eco stresses the distinction between virtual and realised texts). One can then ask, for any particular moment of interpretation, which of these resources was actually used. Keeping the resources separate from the process, analytically speaking, also allows recognition of the ways in which these resources may also be used for the many other contextualising processes which, as part of the overall process of audience reception, 
surround and frame programme comprehension and interpretation. These include anticipation, selection, motivations, conversation, recall, fantasy play, family debate, and so forth. It also flags up the question of how specific extra-textual resources used in interpreting a programme relate to other extra-textual resources (are they compatible, accommodated, modified, kept separate, etc? - this is, in effect, a reformulation of the question of media effects).

Palmer's (1986) study of the lively audience explores how the symbolic and identity relations between children and television change as children develop intellectually. She argues that, 'with the development of an understanding of narratives, of story and character, older children make more complex demands on their favourite TV shows' (p.121). Thus after the age of 8 or 9, children begin to prefer more realistic and more complex programmes instead of the cartoons or toy animal shows they liked earlier. The link between comprehension and interpretation is twofold. Firstly, comprehension of the basic narrative is required for the more differentiated and motivated modes of interpretation which emerge when children begin to make more subtle judgements about genre, about the realism of what is portrayed and about the relation between the drama and their own lives. Secondly, through the interpretation of these more subtle aspects of programmes, older children can incorporate television into their relations with friends and family, fitting its characteristics to their symbolic needs, using what they see not merely to learn about televised events or display media knowledge, but also to define their particular identities, to negotiate friendships through role play or to work out the rules for social interaction in the playground. Consequently, it would be inappropriate to explore children's interpretations and incorporation of television into their daily lives without first knowing how they comprehend the connections, sequencing and conclusions of the narratives, how they determine the modality of realism of different genres or what they know of the production and purpose of programmes. In short, comprehension (or miscomprehension) may set limits on the kinds of interpretation which may follow. There are important differences of gender and social class here, and these contribute to the different interpretations or uses of television for children, but the differences among children of different ages, reflecting different phases of intellectual 
development, are the most striking, affecting children's basic comprehension of the narratives.

A similar argument can be made for adults' comprehension of the news. Robinson and Levy (1986) compared the features of better and worse comprehended stories, and found that (for both Britain and American) stories are better comprehended depending on factors such as personalisation, use of a standard narrative structure, human interest, and so forth. While Findahl and Hoijer (1976) add the news which includes causal information in the story is better comprehended also, stories often include who, what, where and when, but not why, which is needed to integrate the other information. The importance of these textual features makes sense from the point of view of the viewers' resources; they stress the applicability of story grammars used in interpersonal communications as well as mediated communication, they connect everyday patterns of attribution of causality to the comprehension of the news, and the emphasis on human interest encourages the use of everyday social knowledge for 'slot-filling' in the news stories. However, as Gamson (1992) shows, there are different ways of providing this kind of information within the text, so that the news may offer different explanatory frames for the same narrative, casting an event into a frame which, for example, polarizes 'us' and 'them' or which characterises participants as 'feuding neighbours'. Different news events tend to be framed according to diverse but familiar cultural frames which resonate with other sociocultural experiences (Couldry, Livingstone, \& Markham, in press). The textual characteristics which enhance comprehension, one might argue, do so by directing viewers towards particular kinds of interpretation of the news, and these interpretations resonate with yet further cultural understandings, depending on the knowledge, experience and position of the viewer. Consequently, interpretation can guide comprehension. Further, more than 'comprehending what happened yesterday' is at stake, raising questions of the political consciousness and identity of the audience as public (Livingstone, 2005).

The above examples, together with Lewis' and Corner's attempt to formalise the processes involved, may appear to assert a linear theory of making sense of television by proposing an ordered sequence of processes through which viewers pass in making sense of a television programme. While a simple linearity is probably not 
intended by either author, the idea of sequencing the component processes of sensemaking does in itself raise interesting questions. Despite the limitations of a simple linear model of communication transmission, it is plausible, and hence worth exploring, that under certain circumstances, comprehension sets the conditions for interpretation and that, under other circumstances, interpretative frames cue comprehension. Indeed, while the former seems the more obvious point, the main thrust of the constructivist move within social cognition has been to argue that experimental evidence regarding interpretation of simple texts has shown that interpretation cues comprehension, and that, more broadly, diverse types of viewers' responses to texts frame the ways in which processes of comprehension and interpretation occur. In the aptly named 'soap opera effect' (Owens, Bower, \& Black, 1979) for example, in which prior knowledge of a character's motives is responsible for a particular interpretation of subsequent narrative episodes, provides a typical instance of such studies. As the researches in this study noted, giving readers different information about the character's motives (as a basis for inference) resulted in quite different decodings (comprehension) being made of the simple narrative. The argument for reversing the sequence from comprehension to interpretation is also, necessarily, an argument for retaining the distinction between these two processes; and as noted above, a body of empirical evidence for the constructivist processes of narrative interpretation is vital to support both these arguments.

The constructivist reversal of the linear sequence from comprehension to interpretation opens up hermeneutic space between comprehension and interpretation, by recognising that viewers diverge not only in their evaluative response but also in their decoding of characters and events in a television programme. A very clear case for this, from the experimental social cognition literature, is provided by Drabman et al. (1981), in which viewers' expectations led them to reverse the counterstereotypical story when retelling a narrative (as the story made 'better sense' to them with a male doctor and a female nurse than with the male nurse and female doctor presented). Thus a distinction between these processes is required, even though it may well be the case that under conditions, possibly even rather common conditions, viewers do not actually diverge in their inferences or associations (as, for instance, when the inferences invited by the text draw on consensual and little-contested kinds 
of social knowledge). As others have also pointed out (Ang, 1994), a theory of making sense of television requires an acknowledgement of and explanation for the commonalities in viewers' readings as well as of their divergences, and the conditions for the occurrence of both consensual and divergent readings remains an empirical question.

Acceptance of the distinct processes involved in making sense of television need not imply acceptance of a sequential model, as critiqued above. In fact, Corner recognises that a linear model - say, that first the denotative level is comprehended, then the connotational level is interpreted, and then viewers add their own response is inadequate because the levels will interact and the latter will frame the former (Corner, 1991). The extent to which prior cues to interpretative frames are influential in determining programme readings, and the extent to which this may be derived from genre knowledge, or from extra-textual circumstances (as with the example regarding attitudes towards abortion), remain issues for future research. (Posso usar esta afirmativa como gancho para justificar as confusoes geradas na audiência quanto a edição e ao genero do programa)

\section{Text and Effects}

The more one allows making sense of television to be a constructive and nonlinear process, the more problematic is the identification of textual meaning prior to viewers' understanding. Arguably, the specification of meaning in a text prior to its decoding is impossible, for there is no basis for setting up the analyst's interpretation as superior to that of the viewer. This problem is particularly salient in relation to Hall's notion of the 'preferred reading'. Hall (1980) had tried to define the power of the text discursively, suggesting that analysts could identify the ways in which texts placed restrictions on the possible meanings which resourceful readers could construct. The preferred readings 'have the institutional/political/ideological order imprinted in them and have themselves become institutionalised' (p.134). In other words, the preferred reading represents a textual strategy by which viewers' readings are managed through making certain normatively or ideologically preferable readings easier or more readily accessible to them. In this way, one can acknowledge that viewers vary in their response to the text and yet hold on to the notion of media 
effects, by proposing that the encoders are, in general, more powerful in constructing cultural representations than are decoders.

Rather than starting from a theory of power or ideology, Lewis (1991) starts from what is known empirically about texts and audiences to echo the concerns of a number of researchers in arguing that there is no theoretical basis by which to identify this preferred reading. If there is no principled way of distinguishing the researcher's reading from that of the viewers, how might we identify the preferred reading, and is it distinguishable according to inherent features of the text or is it more simply the normative or majority reading actually made by viewers? Such criticisms have more or less led to the abandonment of the concept (Wren-Lewis, 1983) or, at best, to the argument that the preferred reading can only be identified, and hence understood, as the majority audience reading, and so the concept has come to depend on empirical audience research. Lewis illustrates this argument in relation to the Cagney and Lacey abortion story discussed above, by noting that both pro- and anti-abortion viewers retell the narrative in a similar fashion, and so can be said to have grasped the preferred reading (by which he means the majority reading) even though one viewer supports abortion while another opposes it. Hence supporting or opposing the narrative represents a response of the viewer not a quality of the text. More pragmatically, he also argues against the usefulness of the concept of the preferred reading because television meanings are confused, contradictory, or belie any simple preferred meaning. However, in arguing thus, he draws on examples from a 'soapy' cop show and from an audience-participation game show, both of which genres are very different from that of the news and current affairs shows which Hall had in mind, where clear communication is often a priority and where it is more obvious that classbased ideologies are at stake.

There are several problems with this argument. First, it tends to translate a methodological problem into an epistemological one. Undoubtedly we lack methodological procedures for identifying textual readings or structures (in fact, we have also no agreed procedures for determining the majority reading among a group of viewers). Nonetheless, it surely does not undermine a textual analysis to note that television texts are (possibly increasingly) complex and contradictory. More importantly, if we reverse the problem, one can argue that the researcher's 
interpretation of viewers' readings merely represents one reading of their reading, and lacks procedures to lift the analysis out of a relativist quagmire. In other words, if one has the confidence to interpret a viewer's reading, one may, on the same basis, offer an interpretation of the text. A large body of semiotic and literary research at least offers a language with which to do this. For without an analysis of the text, the analysis of communication - of the relations between media institutions, producers, programmes, audiences and cultural contexts - becomes impossible. Despite the difficulties in understanding the reception process, Corner (1995) counsels that 'not to ask questions about precisely how meanings are produced from texts in the act of viewing is to give up on the very idea of television as a cultural process' (p.155). But it remains important to ask not only how viewers interpret television but also how texts invite certain readings rather than others. While the concept of the preferred reading may have been overstretched, many other useful concepts also exist to characterise the ways in which texts implicate viewers in particular ways (e.g. genre, closure, narrative) and their value has not been similarly contested.

Secondly, Lewis drew his example from a relatively closed text, in which the pro-abortion position was favoured, and at the same time, the cultural debate surrounding abortion makes the viewers' response likely to be clearly polarised. In other words, the example permits an analysis in which viewer decoding is seen as fairly simple while viewer response is culturally complex. Nonetheless, it is surely still possible to claim that in this instance, the text presented a certain position, with the result that the pro-abortion viewers found their beliefs supported by the unfolding of the narrative, while the anti-abortion viewers could not find their position reflected in the text. Increasingly, if these events had occurred in a soap opera, the anti-abortion viewer's position would also have been personified by one of the characters and in that sense the text would be open, although a preferred reading may still have been distinguishable. In other words the notion of the preferred reading would appear to apply most clearly to relatively closed texts (as does the case for a two-process rather than a three-process account of decoding).

Thus, Corner's distinction between comprehension and interpretation is most important for relatively open texts, for it is these cases that the second process does not merely fill out the former process, but provides an opportunity for divergence 
among viewers. For a relatively open text, then, such divergence may be permitted, even invited, by the structuring of the text, as well as promoted by the diversity of viewing contexts (as mediated by viewers' responses to the text). Thus while in Lewis' example viewers retold the narrative in a similar way, but diverged in their responses to it, this is not the case in other studies. Particularly in relation to the soap opera, but also, for example in Morley’s Nationwide research (1992), viewers have also been shown to retell a narrative in fundamentally divergent ways, depending on their personal and cultural contexts. Such divergence demands that the process of comprehension (of textual denotation) is separated from those of interpretation (of textural connotation) and response.

It has been a problem that the preferred reading appears, by trying to rescue the power of the text, to have prioritised encoding over decoding, and so tends to collapse Hall's encoding/decoding cyclic model back into a linear transmission model in which meaning flows from sender via message to receiver. As part of the attraction of the coding/decoding model was precisely the possibility of rethinking communication in terms of being ritual, dynamic and culturally located, this has been an unwelcome retreat. Yet, as suggested earlier, the counter-argument may have been too successful, leading to the premature demise of the text within audience research. Thus it may not be merely 'unfortunate' but, rather, indicative that questions of transmission, or effects, tend to return even in a model designed to reframe the theory of communication; the problem of effects will not go away so readily (Millwood Hargrave \& Livingstone, 2006). Indeed, while understanding television cannot be collapsed simply onto questions of influence, this need not argue against questions of power and effects altogether. How then should one theorise links between interpretative processes and media effects? The suggestion implicit in much audience research is that critical readings offer resistance to influence, that passive, comprehension-oriented or referential readings encourage reinforcement or consolidation of past effects, that active, interpretative readings allow for the introduction of new ideas or validation of uncertain associations, and that mindless viewing may enhance mainstreaming effects. But future research is needed to develop these suggestions into research programmes. 
Just as concerns over the transmission assumptions have led to revisions of the encoding/decoding model, for similar reasons the importation of Eco's theory of the role of the reader into media theory underwent a similar transformation. Questions concerning his 'model reader' rather unfortunately tended to get reduced to a simple assumption about authorial intention and hence critiqued as transmission rather than ritual model of communication. To avoid this, the openness of media texts was emphasised over their closure (as if open texts lacked authors) and so attention was focused on the use of extra-textual codes in making sense of television - i.e. social and cultural (or viewer response) factors - at the expense of the use of more directive textual codes which required (and built up) a specific media literacy in the viewer. In other words, more attention has been paid to the role of the reader than to what they are reading, with the result that the focus on the interaction between the two is getting lost. However, there is an important analytic distinction between the author of a text, itself complex in relation to broadcasting institutions, and the characteristics or conventions of that text, a distinction which gets lost under the broad category of 'encoding'. In noting the apparent and repeated incompetence of news producers in foreseeing the comprehension strategies of their audience, Lewis (1991) argues that in practice, news viewers are not at all captured or inscribed by institutionally managed and motivated textual strategies, although they may well be 'captured' by the normative assumptions inherent in conventions of the news genre.

Where does this leave the notion of the active or, possibly, resistant audience? I have argued that active audiences may be considered active in relation to each of these sense-making processes. It is a false association to consider active audiences purely as engaging in ritual, creative or resistant readings, for on the level of comprehension, it makes sense to talk of active and constructive readings, provided this is understood in terms of actively constructing a denotative representation of portrayed events, and not necessarily active in terms of interpretation or other contextual responses. Viewers can be active in their interpretations, without being resistant or counter-normative in the meanings they construct for a programme. Similarly, active audiences may be restricted in relation to each of these processes. Morley (1992) suggests that the limits on audience activity derive primarily not from cognitive limitations but from the limitations on the viewer's resources, where this 
depends on their sociocultural positioning. Undoubtedly, an analysis of the limitations on audience activity is now as pressing as was the recognition of the existence of such activity some twenty years ago. However, given the proposal of several component processes of audience reception, it seems reasonable to propose that each of these processes may impose its own limitations on interpretation. Such limitations may, therefore, be sociocognitive, interpretative, ideological and contextual.

The resistant reader should not be confused with the active reader. Moreover, the much disputed notion of resistance, opposition or subversion among audiences (Seaman, 1992) cannot be resolved simply by pointing to interpretative activity among viewers. Similarly, divergence among viewers is a particularly poor indication of resistance. The question of resistance, I suggest, hangs not so much on the interpretative process but on the relation between the textual and extra-textual resources drawn upon during making sense of television. As noted earlier, as this distinction itself depends on one's analysis of the text, the analysis of resistance (and of normative or dominant readings) depends on the specific political/ideological relations between encoding and decoding. This requires a political analysis which separates out the following kinds of discourses (or norms, or cultural assumptions): general discourses/cultural norms, specific institutional norms and practices, textual/generic norms and conventions, and situated or subcultural norms and contexts of decoding. Most uses of the term 'resistant' or 'subversive' reading presume that these first three are mutually consonant and in conflict with the last. When they are not consonant, one needs to be clear which exactly is being resisted. Lewis points to considerable disjunction between institutional and textual/generic norms in relation to the news, suggesting that the main ideological effects of television are those which escape the producer's intentional control, so that the ideological effectivities of the news text are not those deliberately structured into it, but those which appear, almost inadvertently, as a result of the characteristics of the media, genres, or technologies. Similar arguments have been made about the soap opera, where cultural norms (e.g. gender stereotypes, or romantic myths) are apparently undermined by the generic conventions of the soap opera (marriage never lasts, women are strong), so that an audience reading which is consistent with the genre is nonetheless resistant to the dominant cultural norms. 


\section{Conclusions}

It is a long time since Stuart Hall drew attention to 'a new and exciting phase in so-called audience research' (1980, p.131) which was opening up with the interpretative analysis of audience reception. This proved to be some of the most exciting, interdisciplinary work in the field of media and communications, as researchers from the diverse approaches of uses and gratifications, social cognition, critical communications, popular culture, feminist communications, literary theory and cultural studies simultaneously converged on a common set of arguments about the possibility of active, interpretative audiences and the importance of researching these empirically. While claiming some achievements for this interdisciplinary convergence, I should note that debate remains over the more ambitious hopes on the part of some, albeit resisted by others, for a broader theoretical, epistemological and political convergence of administrative and critical conditions of media research. This is clearly a broader debate, one which focuses on long-standing divisions within the social sciences and humanities, and which will doubtless continue to be debated for years yet.

However, the body of work resulting from this theoretical and methodological convergence on audience reception has been influential, stimulating and informative (Press, 2006; Schroder, Drotner, Kline, \& Murray, 2003). I suggest that the original agenda for audience research has been successful, as the field has moved on from key but problematic old arguments, and cannot return to them. These arguments, challenged by audience reception research, include the semiotics of fixed and given textual meanings, the assertion of linear, causal effects on passive audience (and the simplified accounts of the audience in both uses and gratifications and cultural imperialism theories), and the notions of the homogenous, mass 'audience'. Research has clearly shown that audiences are plural in their decodings, that their cultural context matters and that they cannot be presumed to agree with textual analysis of television programmes. Given that many of these arguments were implicit across many approaches to mass communications, audience reception research has succeeded most importantly in making visible an audience which has hitherto been 
devalued, marginalised and presumed about in both theory and policy within and beyond the field of mass communications.

It is important, however, that as theory continues to be debated, further empirical studies are also conducted to fill out our understanding of the many parameters which frame making sense of television. Following the argument that the core issue of audience reception concerns the dynamic of interaction between text and reception, giving due emphasis also to questions of context, further research should concentrate on these two foci and their interrelations. First, audience reception is structured by textual factors, however understood, such as textual closure, preferred readings, generic conventions, naturalising discourses, dominant ideologies, or subject positioning. Second, audience reception is structured by (psycho)social factors, however understood, such as sociodemographic position, cultural capital, interpretative community, contextual discourses, sociocognitive resources, national identity or psychodynamic forces.

Both textual and social determinations must also be understood in relation to textual and social opportunities for openness, contradiction, agency, polysemy, ambiguity, and so forth, for these play a key role in the analysis of social change, resistance and individuality in the production and reproduction of meanings in everyday life. Thus, no single question need bear the weight of audience research whether it is the issue of resistant voices or contextualised embedded audiences or divergent readings - although nor would I advocate some grand model which combines all variables in a grand scheme, for these are generally reductionist, rigid and functionalist in the end. Rather, the project of audience research depends on seeking out a wide range of specific empirical answers which can elucidate when and where and under what circumstances different kinds of sense-making occur, including for new online as well as broadcast media (Livingstone, 2004). Following this, audience researchers may hope to develop a clearer account not of whether audiences are sometimes active and other times passive or sometimes homogenous and other times divergent, but of why audiences make sense of media in the ways that they have been shown to do. 


\section{References:}

Ang, I.. In the realm of uncertainty: The global village and capitalist postmodernity. In D. Mitchell \& D. Crowley (Eds.), Communication Theory Today. Cambridge: Polity Press, 1994.

Carey, J. W. Communication as culture: essays on media and society. New York: Routledge, 1989.

Collins, W. A. Interpretation and Inference in Children's Television Viewing. In J. Bryant \& D. R. Anderson (Eds.), Children's Understanding of Television: Research on Attention and Comprehension (pp. 125-150). New York: Academic Press, 1983.

Condit, C. The rhetorical limits of polysemy. Critical Studies in Mass Communications, 6(2), 1989.

Corner, J. Meaning, genre and context: the problematics of 'public knowledge' in the new audience studies. In: J. Curran \& M. Gurevitch (Eds.), Mass Media and Society. London: Methuen, 1991.

Corner, J. Television form and public address. London: Edward Arnold, 1995.

Couldry, N., Livingstone, S., \& Markham, T. Media Consumption and Public Engagement: Beyond the presumption of attention. Houndmills: Palgrave, 2007.

Dorr, A. Television and Children: A Special Medium for a Special Audience. Beverley Hills, CA: Sage, 1986.

Drabman, R. S., Robertson, S. J., Patterson, J. N., Jarvie, G. J., Hammer, D., \& Cordua, G. Children's Perception of Media-Portrayed Sex Roles. Sex Roles, 7, 379-389, 1981.

Eco, U. Introduction: The role of the reader. In The role of the reader: Explorations in the semiotics of texts. Bloomington: Indiana University Press, 1979.

Findahl, O., \& Hoijer, B. Fragments of Reality: An Experiment with News and TV - Visuals. Stockholm: Swedish Broadcasting Corporation, 1976.

Gamson, W. Talking Politics. Cambridge: Cambridge University Press, 1992.

Graber, D. A. Processing the News: How People Tame the Information Tide (2nd ed.). New York: Longman, 1988.

Gunter, B. Poor Reception: Misunderstanding and Forgetting Broadcast News. Hillsdale, N.J.: L. Erlbaum Associates, 1987.

Hall, S. Reflections on the encoding/decoding model. In J. Cruz \& J. Lewis (Eds.), Viewing, Reading, Listening: Audiences and Cultural Reception. Boulder: Westview Press, 1994.

Hodge, B., \& Tripp, D. Children and television: a semiotic approach. Cambridge: Polity, 1986.

Katz, E. Viewers' work. In J. Hay, L. Grossberg \& E. Wartella (Eds.), The audience and its landscape (pp. 9-22). Boulder: Westview, 1996. 
Lewis, J. The Ideological Octopus: An Exploration of Television and Its Audience. London: Routledge, 1991.

Livingstone, S. The challenge of changing audiences: Or, what is the audience researcher to do in the internet age? European Journal of Communication, 19(1), 75-86, 2004.

Livingstone, S. (Ed.). Audiences and Publics: When Cultural Engagement Matters for the Public Sphere. Bristol: Intellect Press, 2005.

Livingstone, S. On the material and the symbolic: Silverstone's double articulation of research traditions in new media studies. New Media and Society, 9(1): 16-24, 2007.

Messenger Davies, M. Television is good for your kids. London: Hilary Shipman Ltd, 1989.

Millwood Hargrave, A., \& Livingstone, S. Harm and Offence in Media Content: A review of the evidence. Bristol: Intellect, 2006.

Morley, D. Television, Audiences and Cultural Studies. London: Routledge, 1992.

Osgood, C. E., Suci, G. J., \& Tannenbaum, P. H. The Measurement of Meaning. Urbana: University of Illinois Press, 1957.

Owens, J., Bower, G. H., \& Black, J. B. The "soap opera" effect in story recall. Memory and Cognition, 7(3), 185-191, 1979.

Palmer, P. The Lively Audience: A Study of Children around the TV Set. London: Allen \& Unwin, 1986.

Press, A. Audience research in the post-audience age: an introduction to Barker and Morley. The Communication Review, 9, 93-100, 2006.

Robinson, J. P., \& Levy, M. R. The Main Source: Learning from Television News. Beverly Hills: Sage, 1986.

Schroder, K., Drotner, K., Kline, S., \& Murray, C. Researching Audiences. London: Arnold, 2003.

Seaman, W. R. Active audience theory: Pointless populism. Media, Culture and Society, 14, 301-311, 1992.

Wren-Lewis, J. The encoding/decoding model: Criticisms and developments. Media, Culture and Society, 5, 179-197, 1983. 